\title{
Ambedkar on the Haughty Face of Dignity ${ }^{1}$
}

\author{
Luis Cabrera \\ Griffith University, Brisbane, Australia
}

Politics and Religion, early online January 2020:

DOI: https://doi.org/10.1017/S1755048319000439

\begin{abstract}
Can a concept such as dignity, with roots in hierarchy and exclusion, serve as the constitutional basis for advancing egalitarian justice within democratic political community? This article highlights some concerns, via engagement with the work of Indian constitutional architect and anti-caste champion B.R. Ambedkar. Ambedkar strongly associates dignity with upper-caste status in Hinduism, and with dispositions to haughtiness or arrogance toward lower-status persons. His analysis has implications for recent treatments which frame dignity as a property which is possessed equally by all persons and is suitable for grounding egalitarian justice within political communities. In such accounts, dignity is shown to entail a defensive disposition and indignation against others as potential rights violators. This introduces tensions between the dignitarian foundation and in some cases very expansive social justice aims. Ambedkar offers an alternative conception of innate worth or worthiness, entailing dispositions to openness and inclusiveness, rendered as fraternity, Deweyan social endosmosis, and ultimately the Buddhist maitri. Such an approach avoids some tensions between dignity/indignation and egalitarian aims, while also offering a way to conceptualize human and non-human animal relations that avoids simply reinscribing status hierarchies.
\end{abstract}

\section{Introduction}

Some recent treatments of dignity have sought to show that a concept with its etymological roots in hierarchy and elite privilege can nonetheless serve as the basis for constitutionalizing individual rights and advancing egalitarian distributive and social justice within political community (Waldron 2012a; 2012b; 2013; see Darwall 2017; Gilabert 2018). This article affirms a dignitarian basis for the most fundamental legal human rights, while highlighting some concerns for dignity as a foundational principle in the constitution of political community. It does so via engagement with the work of B.R. Ambedkar (1891-1956), lead

\footnotetext{
${ }^{1}$ I would like to thank for their very helpful comments the two anonymous reviewers for this journal, as well as editor Nicholas Tampio. I also thank Haig Patapan, Komal Rajak, Manjunath Hosamani, Rahul Gajbhiye, Richard Shapcott, Manu Bhagavan and Ferran Martinez i Coma, for their insights and feedback. Any mistakes remaining are my own.
} 
drafter of the 1950 Indian Constitution and champion of the rights of Dalits, formerly called "untouchables." While in the preamble to the Constitution and other charter documents, Ambedkar employed the then-nascent language of dignity, in his own work he firmly associated dignity with its older sense of hierarchical rank. It entailed collective dispositions to haughtiness and indignation, and demands for deference from others accorded lower status within the Hindu caste system.

Ambedkar's treatment calls attention to ways in which even recent egalitarian conceptualizations of dignity are presumed to entail many of the same collective dispositions, especially senses of defensiveness, indignation and resentment against others as potential violators of rights. He offers a nuanced alternative foundation of innately high equal moral worth and status, developed from an emphasis on distinctive human capacities but also engagement with Hindu and Buddhist religious doctrine. He argues that a commitment to recognizing such innate worth/worthiness will primarily entail collective dispositions to political humility, rendered as fraternity, Deweyan social endosmosis, and ultimately the Buddhist maitri. Each is associated with inclusivity and openness toward others as moral and political equals.

The article is structured as follows. The next section presents Ambedkar's analyses of the haughty face of dignity. Then some implications of his claims are assessed for recent treatments, beginning with Jeremy Waldron's well-known account of dignity as comparable to high aristocratic rank -- one that is now available to all persons as equal citizens.

Ambedkar and more recent commentators, notably Stephen Darwall (2017), are shown to pose some significant challenges to such an approach, both in its claims for dignity as a reconstituted aristocratic rank and for dignity as constituted through social or political

\footnotetext{
${ }^{2}$ The term Dalit was popularized among activists from around the 1970s and has become prevalent over 'untouchable' and other terms in many spheres, including the academic. Government agencies continue to use the official term Scheduled Castes (Jaffrelot 2005, 40-41).
} 
practices. Ambedkar's work also indicates a potentially significant challenge for those such as Darwall and Pablo Gilabert (2018), who frame dignity as an innate property entailing dispositions to reciprocity within moral and political community, while acknowledging but not fully addressing tensions introduced by the collective dispositions to indignation and defensiveness also entailed. Ambedkar's conception of high equal moral worth is presented, with emphasis on dispositions to political humility entailed by its full recognition, in particular social endosmosis and maitri. Finally, some insights are taken from Ambedkar's conceptualization of maitri for theorizing relations and status distinctions between humans and non-human animals in ways that avoid some problems identified for Kantian accounts.

\section{Ambedkar on Dignity and Indignation}

Ambedkar's social, legal and political thought has generated increasing interest over roughly the past two decades, as it has become more widely available and scholars from a range of disciplines have explored and engaged it (see Mukherjee 2009; Zene, ed., 2013, Kumar 2015; Nussbaum 2015; 2016; Choudhury 2018; Stroud 2017; Chakrabarty 2019). He is often ascribed a straightforward dignitarian stance on human moral equality and individual rights (Zelliot 2001, 85; Ganguly 2002, 336; Maitra 2012, 302-03; Rodrigues 2017, 104). Such an interpretation would again seem supported by the 1950 Constitution, which promises in its preamble that the new Indian republic would promote "Fraternity, assuring the dignity of the individual..." The same language appeared in the guiding principles Ambedkar drafted in 1956 for the Republican Party of India, intended to serve as the chief national advocacy body for Dalits (Ambedkar 2003[1956], 156). The phrasing reflected that prevalent at the time for charter and related documents, notably the 1945 UN Charter and the 1948 Universal Declaration of Human Rights, which declares that the "recognition of the inherent dignity and 
of the equal and inalienable rights of all members of the human family is the foundation of freedom, justice and peace in the world" (United Nations 1948).

In his own writings and speeches, however, Ambedkar is far less sympathetic to the concept. Dignity is framed as a social property possessed by those of higher status in the Hindu caste hierarchy, who jealously guard it and respond with indignation and anger when they perceive that those of lower standing have not shown them due deference. This understanding was developed in part from his own life experience -- as one who had achieved at an extraordinarily high level but faced continual discrimination because of his low ascribed status in the caste system. Born into a Mahar Dalit family originating in Maharashtra, on India's west coast, Ambedkar had attracted attention from an early age for his intellectual gifts. He was sponsored by the maharaja of the then-princely state of Baroda for overseas study, and he ultimately would complete a PhD. at Columbia, as well as a $\mathrm{DSc}$ at the London School of Economics, besides being admitted to the bar at Gray's Inn, London (see Jaffrelot 2005, 1-7; A. Kumar 2015, 35ff). Despite such accomplishments and his later prominence in Indian civil society and politics, including appointment as chair of the Constitutional Drafting Committee and as the country's first Law Minister, Ambedkar noted that he was routinely treated as 'untouchable' by caste Hindus (1993[1936]).

Dalits were held to fall outside and below the hierarchy of traditional Hindu varnas and the thousands of jatis, or castes and sub-castes within them. They were expected to render unpaid service to higher-caste persons and were typically channelled into the least desirable jobs, for example, manually removing excrement from dry toilets (manual scavenging). They lived in segregation on the edge of villages and were barred from dining with caste Hindus, entering their temples, socializing with or marrying them. As Ambedkar observes:

...they are segregated and shunned because their physical contact is held by the Hindus to cause pollution. ... an Untouchable may not do anything which [will] raise 
him above his appointed station in life. ... An Untouchable must accompany the women folk of the Hindus on their journey from their homes to their parents and vice versa. Their dignity requires that they should have a retinue and the Untouchable is the only available class from which such a retinue can be drawn without any cost. ... Similarly an Untouchable must carry the dead animals out of the village. Indeed he alone must carry them because no Hindu will agree to do scavenging (1989[1938], 133-34; see also Ambedkar 2014[1936], 214-15).

Higher-caste Hindus' sense of dignity is thus explicitly tied to their own elite status in the caste hierarchy. That status is dependent on the existence of an underclass - from which a retinue of subservients may be freely drawn, and against whom elites can measure their own ranking dignity.

Ambedkar presents this haughty face of dignity in his seminal Annihilation of Caste (2014[1936]) and numerous other works. In Annihilation, he notes that in one district in the western Indian city of Ahmedabad, "In November 1935, some Untouchable women of wellto-do families started fetching water in metal pots. The Hindus looked upon the use of metal pots by Untouchables as an affront to their dignity, and assaulted the Untouchable women for their impudence" (2014[1936], 216). In the same text, he recounts an event in Jaipur, southwest of Delhi, where

... an Untouchable of Chakwara who had returned from a pilgrimage had arranged to give a dinner to his fellow Untouchables of the village, as an act of religious piety. The host desired to treat the guests to a sumptuous meal, and the items served included ghee [clarified butter] also. But while the assembly of Untouchables was engaged in partaking of the food, the Hindus in their hundreds, armed with lathis, ${ }^{3}$ rushed to the scene, despoiled the food, and belaboured the Untouchables ... The Hindus of Chakwara ... in righteous indignation avenged themselves for the wrong done to them by the Untouchables, who insulted them by treating ghee as an item of their food-which they ought to have known could not be theirs, consistently with the dignity of the Hindus (2014[1936], 217).

Dignity is tied here to a sense of "righteous indignation." Dalits are perceived by their social superiors to have violated legitimate hierarchical norms. This is met with anger at the

\footnotetext{
${ }^{3}$ Lathis are stout batons used as weapons.
} 
invasion of dignity-as-rank, and with a punishment that caste Hindus see as just because it is in accordance with the prevailing status hierarchy.

The same sense of dignity is presented Ambedkar's chronicling of events leading to a well-known 1927 protest over a communal water source in the town of Mahad, south of Bombay. He details collective action by Dalits in the area, involving in part a refusal to remove or skin dead animals for the higher castes. The object of the actions, he observes, "was to strike a blow at the Hindu Social Order ... which reserves for the Hindus clean and respectable jobs and assigns to the Untouchables dirty and mean jobs and thereby clothes the Hindus with dignity and heaps ignominy upon the Untouchables" (Ambedkar 1989, 185).

In numerous other places, Ambedkar similarly associates dignity with indignation and haughtiness toward those of lower status. It was a dignity depending on graded inequality, a descending hierarchy of rank and service with a mass of persons at the bottom who could be called on to render obeisance and unpaid labor at any time by any of those above. Ultimately, it depended on the availability of a retinue of persons obliged to serve them - but also against which they could contrast their own status.

\section{Implications for Dignity as a Constitutional Foundation}

Ambedkar's approach has potentially significant implications for some more recent accounts, in particular those positing dignity as an appropriate foundational principle for constitutionalizing rights and establishing relations of reciprocity and social/distributive justice within political communities (see Waldron 2012a; 2013; Darwall 2017; Gilabert 2018). Waldron, for example, seeks in part to respond to critiques like Ambedkar's, of dignity as closely conceptually linked to status hierarchies and arrogance toward those deemed to have lower status. His express aim is to reconstitute as an equal rank the hierarchical Roman dignitas, which "embodied the idea of the honor, the privileges, and the 
deference due to rank or office" (Waldron 2012a, 30; 2013, 2). Waldron argues that in modern political community dignity should be similarly understood as a ranking status, but one constituted by law and acquired equally through legal citizenship (Waldron 2012a, 6667). Thus, dignity, "in constitutional and human rights law can be understood as the attribution of a high legal rank or status to every human being ... legal systems constitute and vindicate human dignity, both in their explicit provisions and in their overall modus operandi” (2012a, 66-67; see also Rosen 2012, 12).

He offers numerous examples of past aristocratic law and current aristocraticegalitarian law operating to constitute and uphold dignity, including through protecting individuals' high status - against degradation, against insult (hate speech/crimes), in specifying individuals' rights to make independent choices, and to make moral claims (2012a, 51). The dignity of the legal citizen is also constituted and recognized through the 'self-application' characteristic of law, where individuals are treated as agents capable of consciously interpreting and applying legal norms to their own conduct, rather than as lowranking subjects to be coerced or manipulated. Now, in practice, Waldron says, all citizens are treated as having the highest rank: "Every man a Brahmin. Every man a duke, every woman a queen, everyone entitled to the same sort of deference and consideration..." (2012a, 33-34).

Significantly here, the disposition said to be appropriately adopted by such equal rank holders is a sort of reconstituted horizontal haughtiness, or stance of indignation and defensiveness against possible rights violators. It is marked by "a furious sense of one's rights and a willingness to stand up for them as part of what it means to stand up for what is best and most important in oneself" (2012a, 145). Further, those adopting such a disposition will display an "uprightness of bearing; self-possession and self-control; selfpresentation as someone to be reckoned with" (Waldron 2012a, 22). It is in part his 
affirmation of such a disposition that leads Waldron to reject the grounding of equal status in any conception of human worth or value: "The thing to do with something of value is promote it or protect it, perhaps maximize things of that kind, at any rate to treasure it. The thing to do with a ranking status is to respect and defer to the person who bears it" (2012a, 24, 138).

Waldron thus at least partially acknowledges Ambedkar's critique of the haughty face of dignity, the indignation it entails, but he seeks to frame it as a virtue. Dignity is a jealous status, defensive, even suspicious of others as potential rights violators. Bearers of dignity are persons with whom one must reckon, who hold a "furious" sense of their right to protect their own rights. For Waldron, such a disposition helps to ensure that all persons will be treated with the deference due their high-ranking status.

Ambedkar's work indicates two types of challenges to such an approach. First, it directs attention to questions about whether an account of dignity with its roots in social and political arrogance - demanding deference from perceived inferiors and rejecting their standing to give input or make claims - can be so thoroughly reconstituted as egalitarian. For Ambedkar again, the rank and status of elites depended for its force on the existence of an underclass from which a retinue of followers could be drawn, and against which they could contrast their own status and perceived personal attributes. As he argues in his 1945 book, What Congress and Gandhi Have Done to the Untouchables, both enabled higher-rank persons to view themselves as superior:

The system of Untouchability is a gold mine to the Hindus. In it the 240 millions of Hindus have 60 millions of Untouchables to serve as their retinue to enable the Hindus to maintain pomp and ceremony and to cultivate a feeling of pride and dignity befitting a master class which cannot be fostered and sustained unless there is beneath it a servile class to look down upon. (Ambedkar 1991[1945], 196).

For Ambedkar, the declaration that "their dignity requires that they should have a retinue" again speaks to both the expectations of higher-status persons and the constitutive conditions 
of their dignity-as-rank. Their status is dependent both materially and ideationally on the presence of an underclass. It is a status defined and constituted in relation to that underclass.

Thus, a conception of dignity such as Waldron's which seeks to see “every man a Brahmin" (2012a, 33-34) would be for Ambedkar both incoherent and deeply problematic. To claim that all could enjoy the status and privileges of a Brahmin could be tantamount to claiming, for example, that all animals could summarily be classed as predators. Predators are constituted as a type by their relation to prey. For Ambedkar, there could be no higher-caste Hindus if there were no out-caste persons against which to contrast themselves and establish their status (see also Dimock 2012; Herzog 2012). Below I discuss Rossello's (2017) claims that non-human animals have replaced lower-status humans as the contrasting underclass in Waldron's account.

The second challenge indicated by Ambedkar's work is one concerned with dignity as socially constituted through state citizenship (Waldron 2012a; see also Appiah 2010). We can note first that in some passages on Buddhism, Ambedkar suggests that a socially constituted dignity-as-high-rank might in fact be acquired by those of low ascribed social status, through religious conversion. For example, he asserts of female Buddhist monks that "the Buddha not only opened for them the way to liberty, he also allowed them to acquire dignity, independent of sex" (Ambedkar 2003[1951], 120). More frequently, however, he highlighted the tenuous nature of socially constituted or acquired dignity, including that acquired through high individual achievement. ${ }^{4}$ For example, he observed that

.... a systematic attempt will be made to lower the dignity and status of a meritorious Untouchable. A Hindu leader would be described merely as a great Indian leader. ... If a leader who happens to be an Untouchable is to be referred to he will be described as so and so, the leader of the Untouchables. ... This type of discrimination has its origin in the Hindu view that the Untouchables are an inferior people and however qualified, their great men are only great among the Untouchables (Ambedkar 1989[ca. 1954], 109).

\footnotetext{
${ }^{4}$ Kant also refers to one sense of dignity as acquired through individual initiative, specifically through the fulfillment of moral duty (1999[1785], 51; see also Dean 2006, 59).
} 
Elsewhere, he notes with bitter irony how tensions between his own professionally acquired dignity and caste Hindus' sense of their own dignity-as-rank left him with a broken leg at the bottom of a culvert. This occurred on official business in the Bombay Government region, in the town of Chalisgaon. He was met at the train station by local Mahar Dalits but was left to wait for some time for a horse cart, or tonga. When one finally arrived, the driver proved unable to control the cart, and it overturned while they crossed a low bridge, sending Ambedkar crashing to the rocks below. As he observes:

The delay at the railway station was due to the fact that the tongawalas [professional cart drivers] were not prepared to drive the tonga with a passenger who was an untouchable. It was beneath their dignity. The Mahars could not tolerate that I should walk to their quarters. It was not in keeping with their sense of my dignity. A compromise was therefore arrived at. ... The Mahars may take the tonga but find someone to drive it. ... But they evidently forgot that the safety of the passenger was more important than the maintenance of his dignity. If they had thought of this they would have considered whether they could get a driver who could safely conduct me to my destination. ... It is then I learnt that a Hindu tongawala, no better than a menial, has a dignity by which he can look upon himself as a person who is superior to all untouchables even though he may be a Barrister-at-law (Ambedkar 1993[1936], 681).

These passages offer insight into why conceptualizing dignity primarily as an acquired status, or a status constituted through a set of social norms and practices, can be problematic. A dignity and status that can be acquired can also be 'lowered,' lost, or eliminated. Dignity acquired and recognized in one context may not be recognized in another (see also Darwall 2017, 189-90).

Further, we can note that a set of norms and practices which constitutes and confers dignity on some set of citizen insiders within political community will exclude some outsiders. There could be important implications, for example, for the status and treatment of non-citizens within a state's population, especially those who do not hold authorized immigration status. Waldron responds to such concerns in part by asserting that non-citizens typically are not mistreated by states. For example, in the United States, "The government is 
required to treat everyone in the country with respect and it can be held to account for maltreatment of anyone, citizen or not" $(2013,13)$. Such an assertion may be questionable, but the more essential point here would be that Waldron also presents an imperative to grant good treatment to non-citizens as going "far beyond the dignity of citizenship in the narrow sense" $(2013,13)$ to reflect a respect for universal human dignity. Thus, it appears that a conception of innate human dignity is to be treated as prior to the socially/politically constituted citizen rank. It will provide the baseline conception of dignity and reason for specific sets of citizenship norms and practices to set all persons' status as high in the first place, while also setting parameters on the treatment of non-citizens.

Ambedkar's work thus presents some significant challenges to an account of hierarchical dignity reconstituted as an equal high rank tied to legal citizenship in modern political community. It gives reason to question the logical coherence of a commitment to making "every man a Brahmin." It highlights the fragility or tendencies to exclusion of socially constituted or acquired dignity, and thus why an innate sense of dignity would be implicitly made foundational to address the problem. Ambedkar's work also will indicate a more general challenge to dignitarian accounts, in relation to those which begin with a more straightforward presumption of innate dignity and present it as a suitable constitutional foundation for rights and the advancement of social justice within political community.

We can consider first Stephen Darwall's account. Darwall, besides echoing Ambedkar's concerns with a dignity that could be lowered or lost $(2017,191)$, targets the kinds of collective dispositions entailed by dignity as socially constituted, egalitarianaristocratic rank. He argues that Waldron's and other accounts (Appiah 2010) which seek to establish all individuals as equally ranked "honor peers" in a political community do not actually establish a foundation for individual rights. That is because the status they posit does 
not strictly entail the other-regarding reciprocity, or mutual accountability, that is conceptually essential to rights (Darwall 2017, 193).

Darwall argues that an approach conceptualizing dignity as an innate property equally possessed by all persons will entail such reciprocity, and thus that it will serve as an appropriate constitutional foundation for democratic political community. Significantly, however, he also is clear that the reciprocal collective dispositions presumed to be entailed are ones similar to the haughty - or at least indignant - face of dignity highlighted above. He asserts, for example, that,

We realize second-person respect by relating to one another in ways that acknowledge each other's standing to demand, remonstrate, resist, charge, blame, resent, feel indignant, excuse, forgive and so on. When others "look us in the eye" and claim their rights against us, we recognize their second-personal authority by looking back at them with acknowledgment. ... Attitudes like indignation, resentment, blame, and guilt implicitly address demands to their objects and hold them accountable. They implicitly bid for reciprocating acknowledgment, and unlike purely retaliatory impulses, implicitly acknowledge their object's standing as a fellow member of the moral community (Darwall 2017, 195).

Such a disposition, while it may be more fundamentally reciprocal in the way indicated, is in fact quite close to the stance entailed in Waldron's account, where individuals were to evince a disposition of self-presentation as "someone to be reckoned with" (2012a, 145). It also resonates of the stance Ambedkar ascribed to elites in the Hindu caste system, at least in its defensiveness and emphasis on a disposition to indignation within a dignitarian framework.

That disposition would seem appropriate especially to circumstances in which there are grave threats to the most basic rights, to life, liberty, integrity of person. Defensiveness, suspicion and indignation could be vital to the actual protection of one's own rights in such cases. There could be significant tension, however, between the collective adoption of reciprocal defensive dispositions to indignation, resentment and blame, and the relations of collective reciprocity which actually would advance the discharge of stringent positive duties incumbent within the kind of moral community, or especially liberal-democratic political 
community, that Darwall posits. Dispositions to indignation and defensiveness would be consistent with negative duties and actions against rights invasions, but they do not so clearly support positive duties to advance social and distributive justice, the well-being of others, etc.

Further, the more expansive the distributive/social justice expectations that are laid on a dignity-based political constitution, the more acute the tension becomes. We can consider, for example, Pablo Gilabert's recent account of dignity as the foundation for democratic political community strongly oriented to realizing social justice. In a highly systematic, booklength treatment, Gilabert argues like Darwall for a conception of dignity that is prior to legal/political institutions, and he gives detailed attention to how the recognition of such dignity should inform the design of political institutions and practices (Gilabert 2018, 179-80; see also Vatter 2019). ${ }^{5}$ Full recognition is said to entail a collective disposition to "solidaristic empowerment" oriented to promoting the full flourishing of others within democratic political community:

Solidaristic empowerment takes the dignity of people to call for more than merely sufficientarian schemes. It matters that people have access to the highest levels of human flourishing that can feasibly (and reasonably) be made available, and that no one has less access than others through no choice or fault of their own (Gilabert 2018, 310).

Gilabert thus distinguishes between a basic dignity corresponding to the most basic human rights, and a "maximal dignity" which would support such an expansive social justice scheme (2018, 139-40). The latter, he suggests, would appropriately align with some version of strong democratic socialism (Gilabert 2018, Ch. 11).

Significantly here, he also affirms that persons can "gain a sense of dignity when they act to defend their rights, and a sense of indignity when they are servile and submit to unjust treatment" $(2018,121)$. Yet, such a sense of indignity or indignation, along with the

\footnotetext{
${ }^{5}$ Vatter argues against Waldron for a conception of dignity that entails a pre-institutional, pre-citizenship, "innate legal right (with consequent obligations on all others) to have positive rights under a republican constitution" $(2019,7)$.
} 
resentment, etc., highlighted by Darwall, are significantly downplayed in Gilabert's account overall. The result is that dignity is often presented implicitly as a more generic conception of the equal moral worth of persons, and at times explicitly, as when he states that "By not instrumentalizing people unduly and by exercising concern for them, we acknowledge the value of the features that give rise to their dignity (that is, persons' intrinsic worth)" (Gilabert 2018, 166; see also Gilabert 2018, 152n13).

Gilabert's account is highly sophisticated and persuasive in detailing many implications of a commitment to the equal worth or moral status of all persons. Yet, it does not address in detail the possible tensions between the demanding positive duties to others it presumes within political community, and the defensive dispositions to indignation, resentment and demands for deference that the concept of dignity may inherently entail. To be fully persuasive as an account of maximally egalitarian political community founded on a constitutional basis of dignity, it would need to be able to indicate how such tensions could be resolved.

\section{Ambedkar's Conception of High Equal Worth and Dispositions to Social Endosmosis and Maitri}

Ambedkar, rather than adopting the language of dignity as the marker for what is morally distinctive about humans and should ground a high equal status for them, speaks in terms of a more general innate moral worth or worthiness. His conception of this property is developed from an analysis of some complex human capacities, but also through his engagement with Hindu and especially Buddhist doctrine. He argues that an appropriate interpretation of each will entail more inclusive collective dispositions to fraternity, social endosmosis and later maitri, rather than primarily a stance of defensiveness or indignation toward others.

In his doctrinal analyses, Ambedkar focuses on how some major Indian religious traditions, including a significant current within Hinduism, have affirmed the innate equal 
worth and high equal moral status of persons. For example, in an analysis of the ancient Hindu texts the Upanishads, he identifies groundings for assertions of equal worth in a doctrine of "Brahmaism" (also Brahmanism), ${ }^{6}$ which holds in part that all reality shares the same essence. "For a man to say 'I am Brahma' ... may appear to be impudence. But it can also be an assertion of one's own worth. In a world where humanity suffers so much from an inferiority complex such an assertion on the part of man is to be welcomed" (Ambedkar 1987[1955], 286).

He argues that such a doctrine is superior to Christian or classical Greek thought as a ground for the moral and political equality central to democracy, which "requires that each individual shall know that he is as good as everybody else." He reasons further that "If all persons are parts of Brahma then all are equal and all must enjoy the same liberty which is what Democracy means. ... to recognize and realize that you and I are parts of the same cosmic principle leaves room for no other theory of associated life except democracy (Ambedkar 1987[1955], 286).

Ambedkar expressed frustration that other doctrines affirming the hierarchical caste system had been so dominant within Hinduism, and he made several defenses of conversion from that religion based in its inegalitarian and exclusionary practices. For example, in a 1936 manuscript, "Away from the Hindus," he states: The Untouchables can very well ask the protagonists of Hinduism ... Does Hinduism recognize their worth as human beings? ... Does it say to the Hindus it is a sin to treat the Untouchables as being neither man nor beast? Does it tell the Hindus to love them, to respect them and to do them no wrong? In fine, does Hinduism universalize the value of life without distinction? No Hindu can dare to give an

\footnotetext{
${ }^{6}$ The doctrine is commonly termed Advaita Vedanta. Ambedkar, in using the term "Brahmaism," sought to distinguish it from Brahmanism, a label he used for the doctrine and practices of the varna/caste system's. See also the editors' notes in the critical edition of Riddles in Hinduism: Ambedkar 2016[1955], 172-77.
} 
affirmative answer to any of these questions (Ambedkar 1989[1936], 411-12; see also Choudhury 2018, Ch. 2).

He ultimately settled on conversion to Buddhism, as a religion which appropriately affirmed innate equal worth and high status. He wrote extensively on Buddhist doctrine, developing his own Navayana (new) variant (see Singh 2012). In his posthumously published treatise, The Buddha and His Dhamma (1992[1957]; see also Omvedt 2003, Ch.8), ${ }^{7}$ Ambedkar ascribes to Siddhartha Gautama (ca. 490/450-410/370 BCE) an argument for high innate equal moral worth which begins with an acknowledgment that individuals are "born unequal" in physical and intellectual capacities:

6. All have to enter into what is called the struggle for existence.

7. In the struggle for existence, if inequality be recognised as the rule of the game, the weakest will always go to the wall.

8. Should this rule of inequality be allowed to be the rule of life?

9. Some answer in the affirmative, on the ground that it results in the survival of the fittest.

10. The question, however, is: is the fittest the best from the point of view of society?

11. No one can give a positive answer.

12. It is because of this doubt that religion preaches equality. For equality may help the best to survive, even though the best may not be the fittest. ...

15. This was the viewpoint of the Buddha, and it was because of this that he argued that a religion which does not preach equality is not worth having (Ambedkar 1992[1957]), 308).

The Buddha is thus said to conclude from a stance of intellectual humility, one acknowledging ineliminable limitations on understanding what are genuinely the best capacities in humans and which persons hold them, that a general affirmation of equal moral status is appropriate. ${ }^{8}$

Ambedkar's non-doctrinal groundings in part emphasize differences between the capacities of humans and non-human animals. Thus, they resonate in some ways with Kant's discussion of how all humans possess "the dignity of a rational being," as distinct from other

\footnotetext{
${ }^{7}$ He used Dhamma rather than the more common Dharma, since he associated the latter with religious observations by upper-caste Brahmins in Hinduism (BAWS Vol. 17:2, 2003[1950]), 99).

${ }^{8}$ Compared to Carter 2011. He argues for granting "opacity respect" to all persons which eschews attempts to assess individual capacities beyond some basic threshold.
} 
creatures (Kant 1999[1785], 42). Notably here, Kant rejected any affirmation of the "worth" of a person, as in the setting of a price or value on individuals. He did, however, reference the "worthiness of every rational subject to be a law-giving member in the kingdom of ends..." (Kant, quoted in Waldron 2013, 331; see also Sensen 2017, 248; Vatter 2019, 7-10). Ambedkar similarly presented equal worth as a conception of worthiness, though primarily in the sense that all persons should be seen as innately worthy of inclusion as equals within social and political institutions. ${ }^{9}$ I discuss Ambedkar's non-doctrinal groundings below, highlighting some key distinctions from Kant and others who contrast humans and nonhuman animals.

Here we can turn to the dispositions that Ambedkar saw as chiefly entailed by the recognition of high innate equal worth and status for all persons. These were presented variously as kinship, fraternity, social endosmosis and maitri. Each expresses a stance of openness and inclusiveness toward others, and each was contrasted to the arrogance and exclusion of a system of dignity as caste rank. For example, in "Away from the Hindus," Ambedkar framed conversion from Hinduism expressly as a means of escaping its collective dispositions, or spirit: "The one and the only way to end their social isolation is for the Untouchables to establish kinship with and get themselves incorporated into another community which is free from the spirit of caste" (Ambedkar 1989[1936], 414; see Mukherjee 2009, 359-60; Choudhury 2018, 101-02).

Ambedkar in fact sees a role for a sense of indignation within such a conception of kinship, but it is not a disposition to indignation and resentment against other members of the community. Rather, it is a sense of "sympathetic resentment" directed at those outside the circle of kinship who would violate the rights or reject the equal status of members:

\footnotetext{
${ }^{9}$ It is not clear that Ambedkar ever drew directly on Kant in his work (see Nussbaum 2015), though Kumar $(2015,235)$ notes his critical remarks on any moral categorical imperative operative within the caste system.
} 
It is kinship which generates generosity and invokes its moral indignation which is necessary to redress a wrong. Kinship is the will to enlist the support of the kindred community to meet the tyrannies and oppressions by the Hindus which today the Untouchables have to bear single-handed and alone. Kinship with another community is the best insurance which the Untouchable can effect against Hindu tyranny and Hindu oppression (Ambedkar 1989[1936], 415).

Kinship is presumed to be limited to religious and like communities, and thus to be narrower than any sense of common citizenship. Ambedkar gives more detailed attention in other works to dispositions which would extend to and guide common citizenship practices, including the "fraternity" element of the liberty, equality, fraternity triad of the French Revolution. He had long argued that each should be adopted as a set of core political commitments in India, and each was granted its own line in the Preamble to the Constitution. He reinforces in his late treatise Riddles in Hinduism that "What sustains equality and liberty is fellow-felling: what the French Revolutionists called fraternity. ... Without Fraternity Liberty would destroy equality and equality would destroy liberty. If in Democracy liberty does not destroy equality and equality does not destroy liberty, it is because at the basis of both there is fraternity. Fraternity is therefore the root of Democracy" (Ambedkar 1987[1955], 283).

Fraternity is framed elsewhere as effectively interchangeable with a disposition to social endosmosis. For example, in Annihilation of Caste, Ambedkar states that social endosmosis "is fraternity, which is only another name for democracy. ... It is essentially an attitude of respect and reverence towards fellow men" (2014[1936], 260). The concept of social endosmosis is in some ways more nuanced, however. It originated, as did the view of kinship Ambedkar had adopted, in the work of pragmatist political philosopher and democratic theorist John Dewey, with whom he had studied at Columbia and who exerted profound influence on aspects of his thought (Mukherjee 2009; see Stroud 2017).

Endosmosis is a biological term referring to the movement of fluid through the membranes of a cell. Dewey mentions it once in his 1916 treatise, Democracy and Education, where he 
observes that "a separation into a privileged and subject-class prevents social endosmosis" (1997[1916]), 84). Ambedkar extensively developed the concept and applied it to the Indian context.

For example, in his 1919 submission to the Southborough Committee, which considered some political reforms for India under British imperial rule, he framed social endosmosis as central to the inculcation among societal groups of a sense of "like mindedness" -- of knowledge, aspirations and commitment to norms of reciprocity:

Each group tends to create its own distinctive type of like-mindedness, but where there are more groups than one to be brought into political union, there would be conflict among the differently like-minded. ... It is the isolation of the groups that is the chief evil. Where the groups allow of endosmosis they cease to be evil. For endosmosis among the groups makes possible a resocialization of once socialized attitudes. In place of the old, it creates a new like-mindedness, which is representative of the interests, aims, and aspirations of all the various groups concerned. Like-mindedness ... depends upon the extent of communication, participation or endosmosis (Ambedkar 1979[1919], 249).

He later characterizes the realization of social endosmosis as a society free of caste barriers, where all would be "free to share in an extensive number of common interests ... have a large number of values in common, when there is a free play back and forth, when they have an equable opportunity to receive and to take from others" (Ambedkar 1987[ca. early 1950s], 113; see Ambedkar 2009[1945], 185-87; Mukherjee 2009, 261).

Such a disposition again is significantly distinct from the stance of defensiveness toward others and indignation at possible rights violations that is at least in part entailed by dignity as a constitutional foundation. Ambedkar describes instead a primary disposition to political humility, one entailed by a genuine commitment to recognizing the innate high equal worth and status of others. That is, where political arrogance is the disposition of a hierarchical and exclusive system, political humility entails a disposition to acknowledging the equal moral and political status of others, and an openness to input from them (see Button 2005, 851; 2016). It also entails an intellectual modesty about the finality of one's own judgments - as 
indicated in the intellectual humility he ascribes to the Buddha. Ambedkar's disposition of social endosmosis foregrounds inclusivity and an "opportunity to receive and to take from others."

Ambedkar specifies in his later work that the disposition entailed by a commitment to recognizing high equal worth would be best captured by "what the Buddha called, Maitree," or "maitri" (Ambedkar 1987[1955], 283; see A. Kumar 2015, 328-36). This is a stance of sympathy, amity and benevolence toward all others. It is maitri, he argues in The Buddha and His Dhamma, which does much to transform any Dhamma (Dharma) or doctrine to Saddhamma, a defensible and beneficial doctrine. He cites the Buddha as saying that "Dhamma to be Saddhamma must break down barriers between man and man ... [and] must teach that worth and not birth is the measure of man" (1992[1957], 279).

Further, Ambedkar states that maitri goes well beyond the defensive group disposition to kinship noted above, including species-centric kinship. It involves "extending fellow feeling to all beings, not only to one who is a friend but also to one who is a foe: not only to man but to all living beings," (1992[1957], 128). The next section considers how such a commitment distinguishes Ambedkar's approach from Kant's and others', and may enable it to address some concerns about the status of non-human animals within accounts seeking to affirm high equal status for all persons.

\section{Maitri and the Status of Non-human Animals}

We can begin by noting again Rossello's critique of Waldron's account -- that it simply reconceives humans as aristocrats over an underclass of non-human animals. Humans are situated at the apex of all species, and their high status is ideationally constituted in contrast to other species (Rossello 2017, 757). Such a stance is seen to grant too little concern for the well-being of animals, in the way that many critics have viewed Kant as doing (see Singer 
2009; Kymlicka 2018; though see Korsgaard 2012). ${ }^{10}$ It is effectively framed as a hierarchical haughtiness toward them, and a wholesale discounting or rejection of their interests.

In his non-doctrinal groundings for innate high equal worth/worthiness, Ambedkar does foreground some capacity differences between human and non-human animals. His treatment of the status of non-human animals differs from most others', however, in two significant ways. First, he theorized the equal worth and status of humans in a context where he and other Dalits were routinely treated as having lower status than many animals. Second, the disposition to maitri that he ultimately embraces fundamentally includes animals in its circles of concern. In terms of Dalits' status, Ambedkar highlighted in numerous places that by custom they were treated as "neither man nor beast" (1989[1936], 411). For example, in his famous first exchange with Mohandas Gandhi, who shared Ambedkar's commitment to abolishing untouchability but not his desire to altogether annihilate Hindu occupational/caste distinctions, Ambedkar asked, "How can I call this land my own homeland and this religion my own, wherein we are treated worse than cats and dogs, wherein we cannot get water to drink?" (Ambedkar 2003[1931], 53). ${ }^{11}$

The same contrast between the treatment of Dalits and non-human animals figures strongly in a later critique of "Gandhism" (see Choudhury 2018, 116-24), or Gandhi's political and economic ideal of village-based simplicity and manual production, which Ambedkar called "a return to nature, to animal life" (2009[1945], 272). He argued that larger-scale production and political organization were necessary to advance a more democratic society - to help ensure that none had to endure a life of endless drudgery and toil and provide more equal access to the fruits of modern civilization. The latter included the leisure to develop complex human capacities.

\footnotetext{
${ }^{10}$ Korsgaard acknowledges Kant's assertions that animals may be justifiably treated as nothing more than means to human ends, but she also identifies a case for animal rights in his broader moral and political philosophy.

${ }^{11}$ Contrasts between Ambedkar and Gandhi's social and political visions, and the relations of both to conceptions of political humility, are treated in greater detail in Cabrera 2020, Ch. 2.
} 
Gandhism may be well suited to a society which does not accept democracy as its ideal. ... But a democratic society must assure a life of leisure and culture to each one of its citizens. ... Under Gandhism the common man must keep on toiling ceaselessly for a pittance and remain a brute. In short, Gandhism with its call of back to nature, means back to nakedness, back to squalor, back to poverty and back to ignorance for the vast mass of the people (Ambedkar 2009[1945], 273).

In his engagement with Buddhist thought and ultimate conversion to that religion, Ambedkar turned away from human/animal distinctions in favor of showing due concern for non-human animals. For example, in the oaths prepared for the 1956 ceremony where he led hundreds of thousands of Dalits in conversion to Navayana Buddhism, he included this: "I shall be compassionate to all living beings and I shall nurture them with care" (Ambedkar, quoted in Jaffrelot 2005, 135). In The Buddha and His Dhamma, he cites the Buddha as rejecting animal sacrifices associated with upper-caste Hindus and incorporating animals more explicitly into the circles of concern:

When we think of living things, we begin with distinction and discrimination. We separate friends from enemies, we separate animals we rear from human beings. We love friends and domesticated animals and we hate enemies and wild animals. This dividing line we must overcome and this we can do when we in our contemplation rise above the limitations of practical life. Such was his reasoning." (Ambedkar 1992[1957], 12).

Later in the same text, the Buddha is shown to assert that maitri is the central disposition to be adopted by individuals in relation to all other beings: "Love is not enough; what is required is Maitri. It is wider than love. It means fellowship not merely with human beings but with all living beings. It is not confined to human beings. Is not such Maitri necessary? What else can give to all living beings the same happiness which one seeks for one's own self, to keep the mind impartial, open to all, with affection for every one and hatred for none?" (Ambedkar 1992[1957], 12).

Hatred for none again goes well beyond those with whom one is in relations of close communal kinship, or those who appropriately and reciprocally recognize one's own worthiness and standing. It also includes those who mean ill or even subject one to 
mistreatment. For commentators such as Aishwary Kumar, this use of maitri by Ambedkar is radically inclusive, rejecting a rigid human sovereignty over creatures. It is a concept which "includes all living beings and makes both the adversary and the animal the subject of compassion" (A. Kumar 2015, 331).

Ultimately then, rather than establishing high equal human worth primarily through contrasts with non-human animals, Ambedkar calls for them to be treated with compassion and brought into the circles of maitri: to recognize their worth and treat them with sympathy and a generalized reverence for living beings. At the same time, he calls for the affirmation of high equal moral worth and status for all persons, entailing a collective disposition to openness toward them within political community, consistent with social endosmosis and maitri.

\section{Conclusion}

This article has offered reasons to think that, while a conception of innate human dignity may serve as an appropriate foundation for the most basic human rights, it is more problematic as the constitutional foundation of a democratic political community to be oriented toward egalitarian social justice. Via engagement with Ambedkar's work, it has highlighted ways in which dignity has been tied to hierarchical social and political ranks, entailing primary dispositions to haughtiness and indignation by elites. Much the same disposition to indignation - against others as potential rights violators - continues to feature in recent accounts which frame dignity as the basis for equal moral status and rights, and also as the constitutional basis for egalitarian justice within democratic political community. It was argued that such a disposition may be well suited to defending against grave threats to fundamental rights, but it introduces significant tensions in a scheme of democracy and possibly demanding positive duties of egalitarian justice. 
Ambedkar was shown to offer a nuanced alternative conception of high equal moral worth or worthiness, developed from Hindu and Buddhist doctrine, as well as analyses of distinctions between humans and non-human animals in a context where Dalits were routinely presumed to have lower status than many animals. He argued that the appropriate recognition of such innate worth and status would entail dispositions effectively to openness and inclusivity, in contrast to the endemic haughtiness or arrogance of the caste system. These were rendered as kinship, fraternity, Deweyan social endosmosis, and ultimately the Buddhist maitri. The latter explicitly includes non-human animals in its circles of concern. Such dispositions, it was argued, would better support the robust positive duties to others presumed in some dignitarian accounts, but without the tensions introduced by dignitarian dispositions to defensiveness and indignation.

\section{References}

BAWS refers to B.R. Ambedkar. 1987-2008. Dr. Babasaheb Ambedkar: Writings and Speeches. Vasant Moon and Hari Narake, eds. Bombay: Government of Maharashtra. Vols.122.

Ambedkar, B.R. 1979[1919]. "Evidence Before the Southborough Committee," in Vasant Moon (ed.), BAWS Vol. 1, 247-78.

Ambedkar, B.R. 1987[ca. early 1950s]. "The Hindu Social Order: Its Essential Principles," BAWS Vol. 3: 95-115.

Ambedkar, B.R. 1987[1955]. Riddles in Hinduism: An Exposition to Enlighten the Masses, BAWS Vol. 4: 21-382.

Ambedkar, B.R. 1989. "The Revolt of the Untouchables.” BAWS Vol. 5: 247-58.

Ambedkar, B.R. 1989[1936]. “Away from the Hindus.” BAWS Vol. 5: 403-21.

Ambedkar, B.R. 1989[1938]. “Civilization or Felony.” BAWS Vol. 5: 127-44.

Ambedkar, B.R. 1989[ca. 1954]. The Untouchables, or Children of India's Ghetto, BAWS Vol. 5: 1-124.

Ambedkar, B.R. 1991[1945]. What Congress and Gandhi Have Done to the Untouchables, in Vasant Moon, ed., BAWS, Vol. 9 (1991[1945]), 1-429. 
Ambedkar, B.R. 1992[1957] The Buddha and His Dhamma, BAWS, Vol. 17:2, 9-599.

Ambedkar, B.R. 1993[1936]. "Waiting for a Visa,” BAWS Vol. 12: 661-91.

Ambedkar, B.R. 2003[1931]. “I Have No Homeland,” BAWS, Vol. 17:1, 51-56.

Ambedkar, B.R. 2003[1950]. "Buddha and Future of His Religion," BAWS Vol. 17:2, 97108.

Ambedkar, B.R. 2003[1951]. "The Rise and Fall of the Hindu Woman: Who was Responsible for It?" BAWS Vol. 17, Part 2: 109-29.

Ambedkar, B.R. 2014[1936]. Annihilation of Caste, The Annotated Critical Edition, S. Anand, ed. New Delhi: Navayana.

Ambedkar, B.R. 2016[1955]. Riddles in Hinduism: An Exposition to Enlighten the Masses, The Annotated Critical Selection, S. Anand and Shobhna Iyer, eds., (New Delhi: Navayana, 2016[1955]).

Appiah, Kwame Anthony. 2010. The Honor Code. Princeton: Princeton University Press.

Button, Mark E. 2016. Political Vices. Oxford: Oxford University Press.

Cabrera, Luis. 2020. The Humble Cosmopolitan: Rights, Diversity, and Trans-State Democracy (New York: Oxford University Press).

Chakrabarty, B. 2019. The Socio-Political Ideas of B.R. Ambedkar: Liberal Constitutionalism in a Creative Mould. Abingdon: Routledge.

Choudhury, Soumyabrata. 2018. Ambedkar and Other Immortals: An Untouchable Research Programme. New Delhi: Navayana.

Costa, J.P. 2013. "Human Dignity in the Jurisprudence of the European Court of Human Rights.” In C. McCrudden, ed., Understanding Human Dignity. Oxford: Oxford University Press, 393-402.

Darwall, Stephen. 2017. "Equal Dignity and Rights," in Remy Debes, ed., Dignity: A History. New York: Oxford University Press, 181-201.

Dean, Richard,. 2006. The Value of Humanity in Kant's Moral Theory (Oxford: Clarendon Press Oxford, 2006).

Dewey, John. 1997[1916]. Democracy and Education. New York: The Free Press.

Dimock, Wai Chee. 2012. "High and Low," in J. Waldron, Dignity, Rank, \& Rights, ed. M. Dan-Cohen. Oxford: Oxford University Press, 119-32.

Ganguly, Debjani. 2002. "History's Implosions: A Benjaminian Reading of Ambedkar, Journal of Narrative Theory 32(3): 326-47. 
Gilabert, Pablo. 2018. Human Dignity and Human Rights. Oxford: Oxford University Press.

Herzog, Don. (2012) Aristocratic Dignity? in J. Waldron, Dignity, Rank, \& Rights, ed., M.

Dan-Cohen. Oxford: Oxford University Press, 99-118.

Kant, Immanuel. 1998[1785]. Groundwork for the Metaphysics of Morals, trans. M. Gregor. Cambridge: Cambridge University Press.

Korsgaard, Christine M. 2012. A Kantian Case for Animal Rights, in Margot Michael, Daniela Kühne, and Julia Hänni, eds., Animal Law - Tier and Rect: Developments and Perspectives in the 21st Century (Zurich: Dike Verlag), 3-27.

Kumar, Aishwary. 2015. Radical Equality: Ambedkar, Gandhi and the Risk of Democracy Stanford, CA: Stanford University Press.

Kymlicka, Will. 2018. "Human Rights Without Human Supremacism." Canadian Journal of Philosophy 48(6): 763-92.

Mukherjee, Arun P. 2009. "B.R. Ambedkar, John Dewey and the Meaning of Democracy." New Literary History 402: 345-70.

Nussbaum, Martha. 2015. "Untouchable: Review of Annihilation of Caste: The Annotated Critical Edition, by B.R. Ambedkar." The New Rambler, August 19:

http://newramblerreview.com/book-reviews/religion/untouchable

Nussbaum, Martha. 2016. “Ambedkar's Constitution: Promoting Inclusion, Opposing Majority Tyranny," in Tom Ginsburg and Aziz Huq, eds., Assessing Constitutional Performance. Cambridge: Cambridge University Press, 293-336.

Omvedt, Gail, Buddhism in India: Challenging Brahmanism and Caste (New Delhi: Sage, 2003).

Republican Party [India]. 2003[1956]. "Aims and Objects of the Party.” BAWS 17:2, 156.

Rodrigues, Valerian. 2017. “Ambedkar as a Political Philosopher," Economic \& Political Weekly 52(15): 101-07.

Rossello, Diego H. 2017. "All in the Human Family? Species Aristocratism in the Return of Human Dignity.” Political Theory 45(6): 749-71.

Rosen, Michael. 2012. Dignity: Its History and Meaning. Cambridge, MA: Harvard University Press.

Singer, Peter. 2009. “Speciesism and Moral Status.” Metaphilosophy 40(3/4): 567-81.

Singh, Aakash. 2012. "The Political Theology of Navayana Buddhism,” in Peter Losonczi, Mika Luoma-aho and Aakash Singh, eds., The Future of Political Theology: Religious and Theological Perspectives. Farnham: Ashgate, 159-72. 
Stroud, Scott R. 2017. "What Did Bhimrao Ambedkar Learn from John Dewey's Democracy and Education?" The Pluralist 12 (2): 78-103.

Vatter, Miguel. 2019. "Dignity and the Foundation of Human Rights: Toward an Averroist Genealogy," Politics and Religion, 1-29. DOI:10.1017/S1755048319000336

Waldron, Jeremy, with Wai Chee Dimock, Don Herzog, and Michael Rosen. 2012a. Dignity, Rank, \& Rights, ed. M. Dan-Cohen. Oxford: Oxford University Press.

Waldron, Jeremy. 2012b. "How Law Protects Dignity." Cambridge Law Journal 71(1): 20022.

Waldron, Jeremy. 2013. "Citizenship and Dignity," in Christopher McCrudden, ed., Understanding Human Dignity. Oxford: Oxford University Press, 327-43.

Zelliot, Eleanor. 2001. From Untouchable to Dalit: Essays on the Ambedkar Movement. New Delhi: Manohar.

Zene, Cosimo, ed. 2013, The Political Philosophies of Antonio Gramsci and B.R. Ambedkar: Itineraries of Dalits and Subalterns (Abingdon: Routledge). 